\title{
DEEP THOUGHT vS. LEVY: TWO MOVES CORRECTED
}

The Editors regret greatly that in David Levy's article on his match against Deep Thought, Vol 13, No. 1, pp. 34-36, two typographical slips have crept in. As many readers no doubt will have noticed, going by the logic of the second game (p. 35), '4. ... d6' should be '4 ... a6'. Moreover, in the fourth game (p. 36) the twelfth moves of both players have been omitted, being '12. f4 Nc6'.

\section{INFORMATION FOR CONTRIBUTORS}

Contributors may be interested to know that the ICCA Journal, as of Vol. 10, No. 1, is a source for the Institute for Scientific Information ${ }^{\circledR}$ (ISI) for inclusion in the CompuMath Citation Index ${ }^{\circledR}$ (CMCI $\left.{ }^{\circledR}\right)$, the Automatic Subject Citation Alert (ASCA ${ }^{\circledR}$ ) and SCISEARCH ${ }^{\circledR}$, ISI's on-line database. The Journal is also a source for the Information Company R.R. Bowker for inclusion in the International Serials Database which is a source for Ulrich's International Periodicals Directory and the DIALOG on-line service.

Being included in the CMCI ${ }^{\circledR}$, the ICCA Journal is one of the 400 Journals in mathematics, computer science, statistics, operations research, and related disciplines which is abstracted and/or indexed and/or available as tearsheets; this means that the Journal is accessible in (on-line) database form.

\section{Submission of material}

Contributions to the Journal are welcomed in any form, although preferably by E-mail or on a MS-DOS formatted 5.25 inch diskette. In case contributors prepare their manuscripts with high-quality wordprocessors, it should be noticed that text-files in VENTURA, TEX or TROFF format are processable directly by the Editors, thereby alleviating their task considerably.

\section{ICCA's SPONSORS}

The production of the ICCA Journal depends on authors submitting their articles and on a secretarial staff, first guiding the submissions through the refereeing process and then taking care of the text down to the last detail. The latter is a heavy and time-consuming task.

The Editors and the Board of the ICCA gratefully recognize the SWOL Foundation (Foundation for Scientific Education in Limburg), who provided the Editor-in-Chief for 1990 again with a voluntary grant for part of the support required. Another part of the costs for Vol. 13, No. 2 up to Vol. 14, No. 1, both inclusive, has been contributed by IBM Nederland N.V. The ICCA gratefully acknowledges both sponsorships, but stresses that not all financial problems are solved thereby and therefore wholeheartedly invites new sponsors. 